\title{
Genetic components of characters related to yield in pepper guajillo: Method II of Griffing
}

\author{
Fanny Hernández-Mendoza ${ }^{1 *}$, Tarsicio Corona-Torres ${ }^{1}$ Víctor García-Gaytán ${ }^{2}$, \\ Víctor Heber Aguilar-Rincón', Fernando Carlos Gómez-Merino ${ }^{3}$
}

${ }^{1}$ Colegio de Postgraduados Campus Montecillo, Recursos Genéticos y Productividad. Carretera México-Texcoco, km 36.5, Montecillo, Texcoco, State of Mexico, C.P. 56230, Mexico, ${ }^{2}$ El Colegio de Michoacán, A.C. (LADiPA), Cerro de Nahuatzen 85, La Piedad, C.P. 59699, Michoacán, Mexico, ${ }^{3}$ Colegio de Postgraduados Campus Córdoba, Carretera Córdoba-Veracruz km 348, Manuel León, Amatlán de los Reyes, Veracruz, C.P. 94946, Mexico

\section{A B S T R A C T}

The Capsium genus comprises one of the most economically important and gastronomic plant groups in the world. In Mexico, C. annuum one of the five species was domesticated. Guajillo chili belongs to this species; whose main use is dry. In this type of chili, little is known about its genetic parameters. The objective was to identify populations with better plant characteristics and high yield in order to obtain information on his heterotic patterns. For this study, nine populations of Guajillo chili from different entities of Mexico were used, which by means of a partial dialectic design, originated 36 crosses. The analysis of variance showed highly significant effects $(P \leq 0.001)$ in the general combining ability (GCA) in the parents, as well as for the specific combining ability (SCA) in their crosses mainly in the performance variables. In the variable number of fruit per plant (NFP), a higher GCA was observed, as well as in the cross P1 $x$ P9 that showed higher value of heterosis and heterobeltiosis. The fresh fruit yield, the positive heterotic value, was observed in the crosses P2 x P5, P3 x P4, P3 $\times$ P5, P4 x P9 and P7 x P9. While the yield of dried fruit showed the positive and highly significant heterotic and heterobeltiosis value, at the P1 $\times$ P9 and P2 x P6 crosses. While the cross P3 $\times$ P9 only shows a significant positive value of heterosis.

Keywords: Genetic; Yield; Guajillo; General combining ability; Specific combining ability

\section{INTRODUCTION}

Chili (Capsicum annuиm L.) is one of the five domesticated and most cultivated species for its economic, medicinal and nutritional importance. Currently China (18.2 t), Mexico $(3.4 \mathrm{t})$, Turkey and Indonesia $(2.5 \mathrm{t})$ are top four fresh chili producers while India (1.8 t), China (.321 t), Ethiopia $(.294 \mathrm{t})$ and Thailand $(.247 \mathrm{t})$ are the dried chili producers (Bravo et al., 2006; FAO, 2018). The production of dried peppers has great importance in Mexico, and the Guajillo chili is one of them, used mainly in the preparation of marinades, barbecue and providing a red color in different regional dishes.

According to Gutiérrez et al. (2004) and De la Cruz-Lázaro et al. (2010) mention that to obtain new varieties of plants in plant breeding programs, the most important decision is the selection of parental germplasm and the combinatorial aptitude of the parents. The evaluation of GCA and SCA by dialelic crossing is efficient in the classification of progenitors, as well as the identification of germplasm in plant breeding (Castañón-Nájera et al., 2005). The GCA is translated as the average yield of a line through its hybrid combination, meanwhile, the SCA correspond to certain cases of specific hybrid combinations of good performance in relation to what is observed in their parents (Sprague and Tatum, 1942; Martínez-Vázquez et al., 2017). Therefore, the estimation of these genetic parameters is obtained through the analysis of diallelic designs (four designs) proposed by Griffing (1956).

The value of a genotype depends on its potential per se and its ability to combine. Germplasm evaluation is a decisive aspect in breeding programs (De la Cruz-Lázaro et al., 2010). Particular aspects such as productivity, resistance, tolerance to biotic and abiotic stress, architecture, fruit quality and precocity are fundamental objectives of study in the breeding of the Capsicum genus (Do Rêgo et al.,

\footnotetext{
${ }^{*}$ Corresponding author:

Fanny Hernández-Mendoza, Colegio de Postgraduados Campus Montecillo, Recursos Genéticos y Productividad. Carretera MéxicoTexcoco, km 36.5, Montecillo, Texcoco, State of Mexico, C.P. 56230, Mexico. E-mail: fan298a@hotmail.com
} 
2011). Likewise, the study of the genetic diversity of the genus Capsicum provides parameters for the identification of parents that produce greater heterotic effects and the probability of obtaining superior genotypes in the following generations (Sudré et al., 2005; Costa et al., 2016).

Capsicum is native to the tropical and subtropical Americas, and the majority of the genetic diversity is concentrated in Bolivia, Peru, Brazil, and Mexico (García-Gaytán et al., 2017). Capsicum annuum was domesticated in Mexico thousands of years ago and includes both sweet and spicy fruits, with a myriad of shapes, colors, and sizes (Perry and Flannery, 2007; Wang and Bosland, 2006; García-Gaytán et al., 2017). In Capsicum, it have been realized experiment have examined general combining ability (GCA) and specific combining ability (SCA) (Geleta and Labuschagne, 2006; Hasanuzzaman et al., 2012; Do Nascimiento et al., 2014).

In Mexico, the exploration of the genetic potential of local materials by estimating GCA and SCA has been limited in the case of Capsicum. Pech et al., (2010) estimated the combinatorial aptitude and heterosis of seven Creole populations of "Dulce" chili and the resulting crosses between them, the variables measured were: fruit yield, fruit weight, number of fruits per plant, start harvest, plant height, length and diameter of fruit. They found that the additive effects estimated by the GCA were larger than the dominance effects estimated by the SCA. For their part, Hernández-Pérez et al., (2011) evaluated the GCA and SCA in chili genotypes and their direct crosses. Six types of chili were used: three jalapeño type, yellow Hungarian type and a wide type. The variables evaluated were: days to flowering and cutting, fruit yield per plants, diameter, length and average weight of the fruit and yield per hectare. For both cases in the GCA and SCA they found genotypes and crosses with high yield. Previous studies demonstrate research on the genetic diversity of Capsicum materials in different states of Mexico. However, it is necessary to continue to elucidate its potential for improvement, to achieve progress in obtaining new plants. Therefore, the objectives of the following research were: 1) to evaluate the GCA and SCA of 9 parents and their 36 crosses from Guajillo in a dialelic mating scheme and the evaluation of the parents and the F1 set in one direction on the agronomic basis of yield. 2) Identify the best crosses with high yield potential and good heterosis.

\section{MATERIALS AND METHODS}

\section{Experimental design}

The experiment was conducted in 2015 in a metal greenhouse with plastic cover at the Postgraduate College, Campus Montecillo, Mexico, located at $19^{\circ} 20^{\prime} \mathrm{N}, 3^{\prime} \mathrm{W}$, at an altitude of 2250 masl. The seedlings were transplanted 60 days after germination in white polyethylene bags with dimensions of $40 \times 40 \mathrm{~cm}$ with capacity for $12 \mathrm{~L}$. Red tezontle was used as substrate with granulometry $7 \mathrm{~mm}$. The irrigation system was drip, Steiner nutrient solution was applied (Steiner, 1966), with the following concentrations in $\mathrm{mol}_{\mathrm{c}} \mathrm{m}^{-3} 12.0 \mathrm{NO}_{3}^{-}, 1.0 \mathrm{H}_{2} \mathrm{PO}_{4}^{-1}, 7.0 \mathrm{SO}_{4}^{2-}, 7.0 \mathrm{~K}^{+}$, $9 \mathrm{Ca}^{2+}$, y $4.0 \mathrm{Mg}^{2+}$. The concentrations were modified according to the phenological stage. Vegetables absorb and translocate the nutrients from the roots to the demand and development organs such as leaves, flowers and fruits (Jesus et al., 2020). Once flowering begins, the crosses and selffertilization were carried out to obtain the $F_{1}$ generation. Of the nine populations a partial dialectic was formed with self-fertilization and simple crosses: $1 \times 1,2 \times 3,3 \times 4 \ldots . .9 \times 9$, with a total of 36 crosses and the nine parents.

\section{Vegetal material}

The populations used as the parents were formed, based on the characteristics of size, shape and color of fruit from the states of Durango, Zacatecas, San Luis Potosi and Guanajuato, Mexico (Table 1 and Fig. 1). A partial dialectic was formed with nine parents (populations) with a total of 36 crosses.

For the germination of the seed, of the nine populations of Guajillo chili, 100 seeds from each population were used, which were placed in polystyrene trays with 200 cavities, and as a substrate land of mount, subsequently the trays were stowed and covered with black plastic until germination.

\section{Evaluation of parents and $\mathrm{F} 1$ crosses}

Subsequently the evaluation of hybrids and their parents, it was carried out in 2017, in the La Huasteca Experimental Field-National Institute of Forestry, Agriculture and Livestock Research (INIFAP), located south of Tamaulipas, Mexico. The experiment was established in a randomized complete block design with four repetitions, the experimental unit was represented by

\begin{tabular}{|c|c|c|}
\hline Population & Description & Origin \\
\hline $\mathrm{P} 1$ & Guajon Red Guajillo & $\begin{array}{l}\text { Dgo. Zac. y Villa de } \\
\text { Reyes SLP }\end{array}$ \\
\hline P2 & Intermediate Red Guajillo & $\begin{array}{l}\text { Dgo. Zac. y Villa de } \\
\text { Reyes SLP }\end{array}$ \\
\hline P3 & Small Red Guajillo & $\begin{array}{l}\text { Dgo. Zac. y Villa de } \\
\text { Reyes SLP }\end{array}$ \\
\hline P4 & Guajon Red Guajillo & San Luis Potosí \\
\hline P5 & Intermediate Red Guajillo & San Luis Potosí \\
\hline P6 & Small Red Guajillo & San Luis Potosí \\
\hline P7 & Guajon Red Guajillo & Guanajuato \\
\hline P8 & Intermediate Red Guajillo & Guanajuato \\
\hline P9 & Small Red Guajillo & Guanajuato \\
\hline
\end{tabular}


a plot of $1.84 \mathrm{~m} 2$ useful (two rows of $2 \mathrm{~m}$ long by $0.92 \mathrm{~cm}$ wide). The experimental unit was represented by a plot of $1.84 \mathrm{~m} 2$ useful (two rows of $2 \mathrm{~m}$ long by $0.92 \mathrm{~cm}$ wide).

The characters evaluated, according to the descriptor manual for Capsicum (IPGRI, 1995) were: plant height (AP), canopy cover (CD) (cm), height of the first fork (APB) (cm); fresh fruit weight (PFF) (g), dry fruit weight (PFS) (g), for these two characters the average weight of 12 fruits was taken, fruit length $(\mathrm{LF})(\mathrm{cm})$, fruit width $(\mathrm{AF})$ $(\mathrm{cm})$, peduncle length $(\mathrm{LP})(\mathrm{cm})$, and number of fruits per plant (NFP); yield of dry fruit $\left(\mathrm{RFS}, \mathrm{t} \mathrm{h}^{-1}\right)$ and yield of fresh fruit $\left(\mathrm{RFF}, \mathrm{th}^{-1}\right)$. The evaluation of the plant variables was carried out in four plants in each experimental unit and that of the fruits in three fruits per plant. The evaluation of the green and dry yield variables was carried out considering

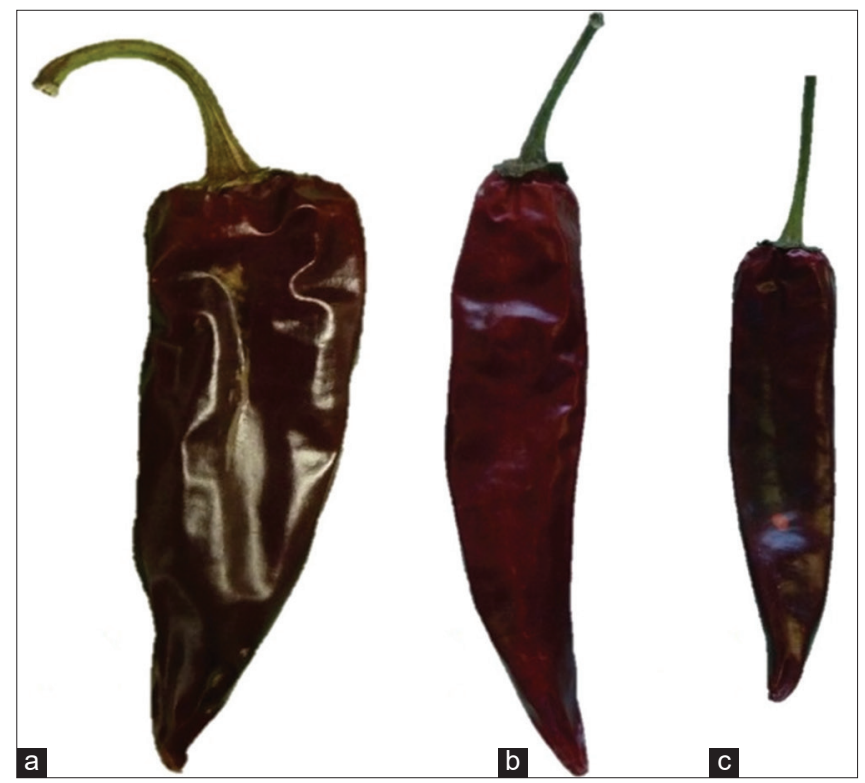

Fig 1. Fruit form of the accessions of the nine populations of Guajillo chili in Mexico (a) Guajon Red Guajillo, (b) Intermediate Red Guajillo and (c) Small Red Guajillo. all the plants of the experimental unit according to the following Equation 1:

$$
\begin{aligned}
\mathrm{t} \mathrm{ha}^{-1}=\left[\left[10,000 \mathrm{~m}^{2} / \text { useful plot }\left(1.84 \mathrm{~m}^{2}\right)\right]^{*}\right. \text { yiel } \\
\text { of the plot }]]
\end{aligned}
$$

\section{Data analysis}

An analysis of variance (ANOVA) was performed on the experimental data and the means were compared by the Tukey test $(\mathrm{P} \leq 0.05)$, with the SAS statistical package ver. 9.3. Percentage heterosis $(\mathrm{Hm})$ was estimated with respect to the average of each of the agronomic and yield variables. The herterobeltiosis $(\mathrm{Hs})$ was estimated percentaje of deviation of the $F_{1}$ hybrid from better parental value. By means of the "t" test described by Wynne et al. (1970) the significance of heterosis and heterobeltiosis was evaluated with respect to the average of the parents. The general combining ability (GCA) and specific (SCA) were calculated following method 2 of Griffing's dialelic (Griffing, 1956). The DIALLEL-SAS program estimated the effects of GCA and SCA (Zhang and Kang, 2003).

\section{RESULTS AND DISCUSSION}

Analysis of variance of parents and their F1 crosses The analysis of variance showed highly significant differences in parents and F1 crosses in most of the variables, except in $\mathrm{CD}, \mathrm{APB}$ and AF (Table 2). Highly significant effects $(\mathrm{P} \leq 0.001)$ of the GCA were observed in seven of the 11 variables, while SCA had highly significant differences in RFF, RFS, PFS and significant AP, LF and NFP. The lowest coefficient of variation between the variables was observed in the length of fruits (LF) (6.92\%), pedicel length (LP) $(7.39 \%)$ and plant height (AP) $(9.23 \%)$. While in the NFP, RFF and RFS variables it was greater than $20 \%$ (Table 2). Shows the F1 fruits of the crosses developed in the greenhouse

\begin{tabular}{|c|c|c|c|c|c|c|}
\hline \multirow[t]{2}{*}{ Variables evaluated } & \multicolumn{6}{|c|}{ Variance analysis } \\
\hline & Repetition & Parents and F1 crosses & GCA & SCA & Error & CV (\%) \\
\hline df & 3 & 44 & 8 & 36 & 132 & \\
\hline Plant height $(\mathrm{cm})$ & $438.22^{\star *}$ & $111.10^{*}$ & 75.98 & $118.91^{*}$ & 73.22 & 9.23 \\
\hline Docel coverage $(\mathrm{cm})$ & $950.06^{\star *}$ & 58.89 & 52.66 & 60.28 & 48.32 & 10.25 \\
\hline Height of the first bifurcation (cm) & 5.90 & 2.55 & 4.85 & 2.05 & 2.53 & 27.82 \\
\hline Number of fruits per plant & $60.61^{\star *}$ & $24.89^{\star \star \star}$ & $52.24^{\star * *}$ & $18.81^{*}$ & 11.81 & 25.07 \\
\hline Fruit length $(\mathrm{cm})$ & 1.22 & $1.87^{* \star *}$ & $4.90^{\star * *}$ & $1.20^{*}$ & 0.81 & 6.92 \\
\hline Fruit width $(\mathrm{cm})$ & 0.28 & 0.30 & 0.61 & 0.23 & 0.37 & 14.79 \\
\hline Peduncle length (cm) & 0.37 & $0.34^{\star \star \star}$ & $0.85^{\star \star \star}$ & 0.23 & 0.17 & 7.39 \\
\hline Fresh fruit weight (g) & 16.81 & $29.05^{\star * *}$ & $80.93^{* * *}$ & 17.52 & 14.30 & 10.74 \\
\hline Dry fruit weight $(\mathrm{g})$ & 0.51 & $1.00^{* * *}$ & $225.43^{\star \star}$ & $125.06^{\star *}$ & 0.48 & 12.74 \\
\hline Fresh fruit yield (t ha- 1 ) & $23.22^{*}$ & $19.54^{\star * *}$ & $28.45^{\star * *}$ & $17.56^{\star * *}$ & 7.96 & 22.50 \\
\hline Dry fruit yield (t ha-1) & $2.70^{\star *}$ & $1.84^{\star \star *}$ & $3.74^{\star \star *}$ & $1.42^{* * *}$ & 0.63 & 26.38 \\
\hline
\end{tabular}

Table 2: Mean squares of the analysis of variance for agronomic characteristics and yield in populations of Guajillo chili

*, **, **: aSignificant at $0.05,0.01$, and 0.001 respectively. GCA = general combining ability; SCA = specific combining ability; CV = coefficient of variation; $\mathrm{df}=$ degrees of freedom. 


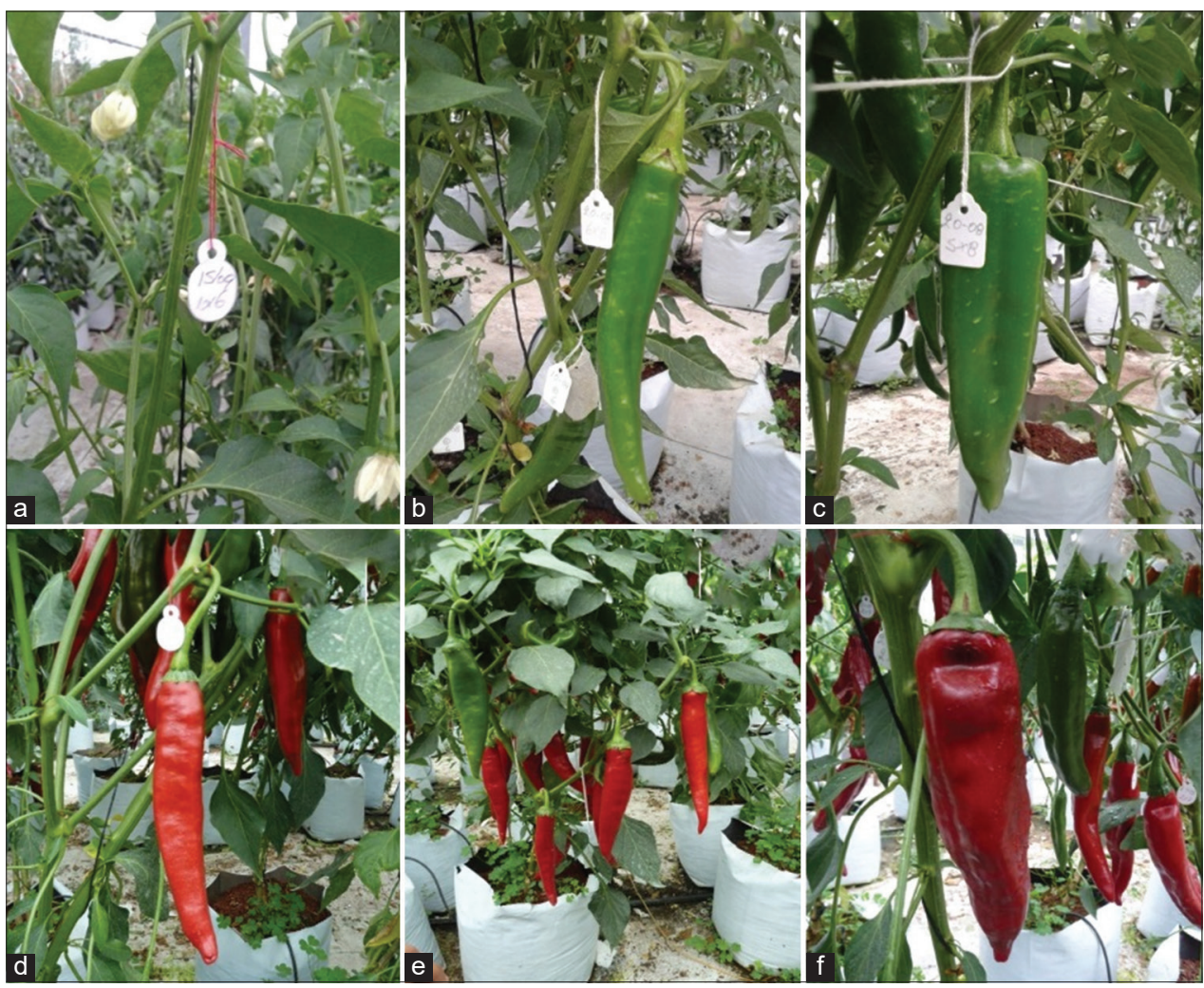

Fig 2. Generation of $F 1$ seeds developed in a greenhouse. Flowering and crosses (a), immature fruit obtained from the cross (b), and development of the fruit obtained from the cross (c). Fruit ripening, Intermediate Red Guajillo (a), Small Red Guajillo, (b) Guajon Red Guajillo.

(Fig. 2). Fruits of the F1 crosses developed in the field to obtain F2 seeds (Fig. 3).

The results show the existing variation in the populations and their crosses, which is because these populations come from a broad genetic base. Similar results have been reported in RF, NFP, AP and LF in sweet pepper (May et al., 2010). The GCA of the populations and their crosses differed significantly ( $\mathrm{P} \leq 0.001)$ in NFP, LF, LP, PFF, PFS, as well as the RFF and RFS in tha ${ }^{-1}$. In the case of the GCA, significant differences were observed in the variables NFP, LF, LP, PFF, PFS, RFF Y RFS and for ACE in the variables AP, NFP, PFS, RFF and RFS. As seen in Table 2, the GCA are greater in magnitude than the SCA in most of the variables except in AP (75.98) and CD (52.6). Therefore, the evaluated germplasm characters were associated more with additive effects than with non-additive ones, indicating that satisfactory gains can be achieved with the selection of these characters (Medeiros et al., 2014). Similar results were observed by Medeiros et al. (2014) and Sitaresmi et al. (2016) who report that the NFP, PF LF, DF of C. annumm, and C. baccatum var. Pendulum, were more associated with additive effects.

For SCA, significant effects $(\mathrm{P} \leq 0.05)$ were found on AP, NFP, LF and highly significant $(\mathrm{P} \leq 0.001) \mathrm{PFS}, \mathrm{RFF}$ and RFS, indicating the presence of non-additive genetic action (dominance) in these characters (Table 2). Similarly,

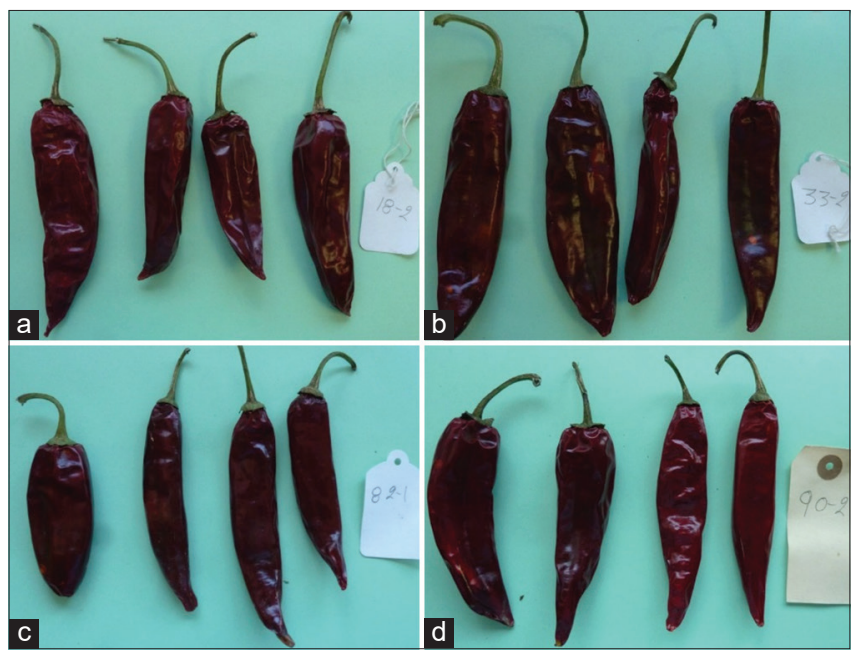

Fig 3. Fruits of the F1 crosses ((a), (b), (c), (d)) developed in the field to obtain F2 seeds.

Esquivel-Esquivel et al. (2011) observed significant effects for ACE in NFP, DF and PPF; while Pech et al. (2010) reported that in sweet pepper they did not observe significance in PFF, AP and LF.

\section{Comparison of means of crosses and populations of the evaluated variables of Guajillo chili}

In the case of the comparison of means, only 11 of the 36 crosses with the highest yield and the nine parents 
involved were taken (Table 3). In addition, it is observed that of the eight variables analyzed there were differences greater than $20 \%$ in the average of RFS, RFF, and NFP of the crosses with respect to the average of populations. While in the rest of the variables analyzed the differences were less than $10 \%$. The increase in the yield of the RFS variable, it is considered very important because this type of chili is consumed dry, and it is also related to the increase in NFP.

In this case, only the populations P5 and P8 present statistical differences in the RFS, although all the populations present higher yields of 2 to $4 \mathrm{tha}-1$, values above the national mean of $1.46 \mathrm{t} \mathrm{ha}^{-1}$, except for population 8 . The results of the highest yield are explained by the origin of the populations, because they come from collections that were selected for presenting higher yields.

Although there were only statistical differences between the P5 and P8, the P5 stands out along with the P4 and P7 for presenting higher yields in RFS, RFF and in the NFP. Such populations could be selected to be used as varieties per se.

Regarding the LF variable of the populations, they ranged from 11.16 for P6 to 13.54 for P4. The difference of these last three populations, with the rest, it may be because they come from the selection of fruits that were called Guajillo small fruit; while for the variables AP and LP they did not present statistical differences between the different populations.

For plant height (AP) it is observed that the crosses $\mathrm{P} 1 \mathrm{x}$ P9, P3 x P7 and P4 x P9 have a height greater than one meter and the rest ranges from 0.77 to $0.98 \mathrm{~m}$. These results suggest that, for this type of chili, a higher plant height does not necessarily imply a higher fruit yield. In genetic improvement, plant height becomes relevant when considering the type of management to which it will be subjected; thus, compact and medium-sized plants are ideal for field cultivation, while tall plants or plants with undetermined growth habits will be optimal for greenhouse cultivation (Greenleaf, 1986; May et al., 2010).

With the cross P5 x P6 it was higher and the highest NFP (18.6) was obtained with respect to the populations and crosses, in the cross P2 x P5 I present the highest LF. Obtaining the highest PFF was possible with the crosses P2 x P5 (38.75 g) and P7 x P9 (38.54 g), regarding populations (Table 3).

The highest RFF is observed in the cross $\mathrm{P} 4 \times \mathrm{P} 9$, which may be because it is one of the crosses with the highest NFP, LF and AP. However, despite the high RFF, a greater number of green fruits $(\mathrm{CONV}=4.28)$ is required to obtain a ton of dried fruit; while P3 x P9 obtained the lowest RFF (11.13), an average of 15 fruits per plant

Table 3: Comparison of means of the populations and crosses of the Guajillo pepper of the evaluated variables

\begin{tabular}{|c|c|c|c|c|c|c|c|c|c|}
\hline Population and crosses & RFS & CONV & RFF & PFF & PFS & NFP & LF & AP & LP \\
\hline $\mathrm{P} 1$ & $2.74 \mathrm{a}-\mathrm{d}$ & 4.44 & $12.17 \mathrm{a}-\mathrm{d}$ & $37.29 a b$ & $5.62 \mathrm{a}$ & $13.00 \mathrm{a}-\mathrm{c}$ & $12.85 a b$ & $93.75 a b$ & $5.81 \mathrm{a}-\mathrm{c}$ \\
\hline P2 & 2.64 a-d & 4.92 & $12.99 \mathrm{a}-\mathrm{d}$ & $33.96 \mathrm{ab}$ & $5.33 \mathrm{a}$ & $13.44 \mathrm{a}-\mathrm{c}$ & $12.88 \mathrm{ab}$ & $93.94 \mathrm{ab}$ & $5.53 \mathrm{a}-\mathrm{c}$ \\
\hline P3 & $3.02 \mathrm{a}-\mathrm{d}$ & 3.41 & $10.31 \mathrm{a}-\mathrm{d}$ & $30.84 a b$ & $4.71 \mathrm{a}$ & $14.53 \mathrm{a}-\mathrm{c}$ & $11.58 \mathrm{ab}$ & $89.69 a b$ & $5.15 \mathrm{a}-\mathrm{c}$ \\
\hline P4 & $3.85 \mathrm{a}-\mathrm{d}$ & 3.74 & $14.40 \mathrm{a}-\mathrm{d}$ & $32.71 \mathrm{ab}$ & $4.86 \mathrm{a}$ & $16.43 a b$ & $13.54 a b$ & $92.31 \mathrm{ab}$ & $5.94 \mathrm{a}-\mathrm{c}$ \\
\hline P5 & $4.15 \mathrm{a}$ & 3.29 & 13.67 a-d & $32.30 \mathrm{ab}$ & $4.92 \mathrm{a}$ & $15.75 a-c$ & $11.22 \mathrm{~b}$ & $85.75 a b$ & $5.42 \mathrm{a}-\mathrm{c}$ \\
\hline P6 & 2.99 a-d & 3.75 & $11.23 \mathrm{a}-\mathrm{d}$ & $30.63 \mathrm{ab}$ & $4.85 \mathrm{a}$ & $13.86 \mathrm{a}-\mathrm{c}$ & $11.16 \mathrm{~b}$ & $96.19 a b$ & $4.98 \mathrm{c}$ \\
\hline P7 & 3.39 a-d & 3.93 & $13.34 \mathrm{a}-\mathrm{d}$ & $36.04 \mathrm{ab}$ & $5.15 \mathrm{a}$ & $13.45 \mathrm{a}-\mathrm{c}$ & $13.16 a b$ & $97.84 \mathrm{ab}$ & $5.96 \mathrm{a}-\mathrm{c}$ \\
\hline P8 & $1.50 \mathrm{~cd}$ & 4.68 & $7.02 \mathrm{~cd}$ & $32.92 \mathrm{ab}$ & $4.56 \mathrm{a}$ & 8.50 bc & $12.99 \mathrm{ab}$ & $83.50 \mathrm{ab}$ & $5.66 \mathrm{a}-\mathrm{c}$ \\
\hline P9 & $2.31 \mathrm{a}-\mathrm{d}$ & 4.54 & $10.51 \mathrm{a}-\mathrm{d}$ & $34.79 a b$ & $5.26 \mathrm{a}$ & $12.35 \mathrm{a}-\mathrm{c}$ & $12.36 \mathrm{ab}$ & $94.56 \mathrm{ab}$ & $5.51 \mathrm{a}-\mathrm{c}$ \\
\hline Mean & 2.95 & 4.08 & 11.74 & 33.50 & 5.02 & 13.48 & 12.42 & 91.95 & 5.55 \\
\hline P1×P9 & $3.90 \mathrm{ab}$ & 3.7 & $14.44 \mathrm{a}-\mathrm{d}$ & $36.04 \mathrm{ab}$ & $5.76 \mathrm{a}$ & $17.32 \mathrm{ab}$ & $13.19 a b$ & $101.75 \mathrm{a}$ & $5.55 \mathrm{a}-\mathrm{c}$ \\
\hline $\mathrm{P} 3 \times \mathrm{P} 4$ & $3.90 \mathrm{ab}$ & 4 & $15.62 a b$ & $36.25 a b$ & $6.01 \mathrm{a}$ & $17.00 \mathrm{ab}$ & $13.27 \mathrm{ab}$ & $97.00 \mathrm{ab}$ & $5.86 \mathrm{a}-\mathrm{c}$ \\
\hline $\mathrm{P} 4 \times \mathrm{P} 6$ & $3.89 a b$ & 3.2 & $12.48 \mathrm{a}-\mathrm{d}$ & $35.00 a b$ & $5.62 \mathrm{a}$ & 15.20 a-c & $13.93 \mathrm{a}$ & $98.50 a b$ & $6.00 \mathrm{a}-\mathrm{c}$ \\
\hline $\mathrm{P} 2 \times \mathrm{P} 6$ & $3.82 a b$ & 3.97 & $15.17 \mathrm{ab}$ & $34.58 \mathrm{ab}$ & $5.63 \mathrm{a}$ & $17.05 \mathrm{ab}$ & $12.87 \mathrm{ab}$ & $92.63 \mathrm{ab}$ & $5.28 \mathrm{a}-\mathrm{c}$ \\
\hline P3×P5 & $3.79 a b$ & 3.3 & $12.53 \mathrm{a}-\mathrm{d}$ & $34.58 \mathrm{ab}$ & $5.46 \mathrm{a}$ & 15.28 a-c & $13.45 a b$ & $94.94 \mathrm{ab}$ & $5.04 \mathrm{bc}$ \\
\hline P4×P9 & 3.76 a-c & 4.28 & $16.10 \mathrm{a}$ & $37.71 \mathrm{ab}$ & $6.02 \mathrm{a}$ & $16.83 a b$ & $13.46 a b$ & $101.00 a b$ & $5.83 a-c$ \\
\hline $\mathrm{P} 5 \times \mathrm{P} 6$ & 3.68 a-c & 4.16 & $15.32 \mathrm{ab}$ & 28.54 b & $4.59 a$ & $18.60 \mathrm{a}$ & $12.65 a b$ & $96.00 \mathrm{ab}$ & $5.52 \mathrm{a}-\mathrm{c}$ \\
\hline P3xP9 & $3.60 \mathrm{a}-\mathrm{c}$ & 3.09 & $11.13 \mathrm{a}-\mathrm{d}$ & $32.30 \mathrm{ab}$ & $5.35 a$ & $14.58 \mathrm{a}-\mathrm{c}$ & $12.51 \mathrm{ab}$ & $88.06 \mathrm{ab}$ & $5.60 \mathrm{a}-\mathrm{c}$ \\
\hline P3×P7 & 3.57 a-d & 3.51 & $12.54 \mathrm{a}-\mathrm{d}$ & $34.38 \mathrm{ab}$ & $5.43 \mathrm{a}$ & $14.10 \mathrm{a}-\mathrm{c}$ & $12.77 \mathrm{ab}$ & 101.19ab & $5.74 \mathrm{a}-\mathrm{c}$ \\
\hline $\mathrm{P} 2 \times \mathrm{P} 5$ & $3.45 \mathrm{a}-\mathrm{d}$ & 4.23 & $14.62 \mathrm{a}-\mathrm{c}$ & $38.75 a b$ & $5.86 \mathrm{a}$ & 15.70 a-c & $13.86 \mathrm{a}$ & $98.25 a b$ & $5.79 a-c$ \\
\hline P7×P9 & 3.44 a-d & 4.03 & $13.88 \mathrm{a}-\mathrm{d}$ & $38.54 a b$ & $6.06 \mathrm{a}$ & $15.70 \mathrm{a}-\mathrm{c}$ & $13.20 a b$ & $81.87 a b$ & $5.50 \mathrm{a}-\mathrm{c}$ \\
\hline Mean & 3.71 & 3.77 & 13.98 & 35.15 & 5.61 & 16.12 & 13.20 & 91.56 & 5.61 \\
\hline
\end{tabular}

${ }^{a}$ Means with different letters in a column are statistically different (Tukey $\left.\mathrm{P} \leq 0.05\right)$. RFS: Yield of dried fruit ( $\mathrm{t}$ ha-1); RFF: Yield of fresh fruit ( $\mathrm{t}$ ha-1); CONV: RFF to RFS conversion ( $\mathrm{t} \mathrm{ha} \mathrm{a}^{-1}$ ); PFF: Average weight of fresh fruit (g); PFS: Average weight of dried fruit (g); NFP: Number of fruits per plant; LF: Fruit length (cm); AP: Plant height $(\mathrm{cm})$; LP: length of pedicel $(\mathrm{cm})$ 
and less in LF and AP. The advantage of this cross over the others is that it requires fewer units of green fruit $(\mathrm{CONV}=3.09)$ to provide a ton of dried fruit. Both P3 and P9 are small fruit Guajillo's and come from distant places, that is, Zacatecas and Guanajuato, respectively. In addition, it can be seen that in the crosses where P9 intervenes as a male, two of those crosses (P1 x P9, P4 x P9) have the highest $\mathrm{PA}$ and in the crosses (P3 $\mathrm{P}$ P and $\mathrm{P} 7 \times \mathrm{P} 9)$ they have the smallest plants height.

These results highlight that there is great variability between crosses and populations for the yield variables. Similarly, Do Nascimiento et al. (2014) in C. annuum and Patel et al. (2010) also reported coincident results regarding fruit length. According to Sitaresmi et al. (2016), showed that in the crosses they made, observed a higher weight of fruit per plant, as well as a greater number of fruits per plant, which shows the great advantages of obtaining genetic traits by crossing between populations of Capsicum spp.

\section{Combinatorial capacity of the Guajillo pepper populations}

The Table 4 shows that general combining ability is important for the selection of appropriate parents in hybridization, since it gives an idea if a particular population combines well in a cross (Nagaraju and Sreelathakumary, 2017). $P 5$ showed a positive and significant value $(P \leq 0.05)$ in GCA in the NFP variable $\left(1.08^{*}\right)$, followed by P6 $(0.97 *)$, while P8 $(-1.94 * * *)$ showed the lowest value, highly significant but negative, for the same variable. However, P5 in the PFF variable showed a negative effect on the GCA (-0.22), indicating that P5 produced a higher NFP but low weight. In contrast, P1 showed a highly significant positive value $(\mathrm{P} \leq 0.001)$ of $\mathrm{GCA}$ for the $\mathrm{PFF}$ variable, but a highly significant and negative effect on the NFP variable $\left(-1.53^{* *}\right)$, which indicates that said behavior is inverse since few fruits per plant were produced, but with greater weight.

The GCA values for the RFS variable (t ha-1), P5 was the best, followed by P4; while the one with the lowest GCA value was P8. These populations show positive and significant values of GCA in the variables RFF, LF and LP in P4, while P5 only in NFP (Table 4). P5 showed a significant difference in NFP, indicating that the plant had a good number of fruits and a PFF not very heavy, but that is reflected in the higher RFS $t_{h a}{ }^{-1}$. For P4, although it did not show significant differences in NFP, its PFF was also high, which was reflected in both RFF and RFS $\mathrm{tha}^{-1}$. For P4, although it did not show significant differences in NFP, its PFF was also high, which was reflected in both RFF and RFS $t h^{-1}$.

\section{Specific combining ability, heterosis and heterobeltiosis in Guajillo chili crosses}

Specific combining ability (ACE) measures the specific behavior of each hybrid in relation to its corresponding parents and estimates the dominant genetic effects (Sprague and Tatum, 1942). Both heterosis and heterobeltiosis are biological phenomena that have aroused interest due to their importance in plant genetic improvement. The results of these phenomena are shown in Table 5, 6 and 7.

The significant SCA effects for RFF were presented in the $1 \times 9$ and $3 \times 4$ crosses, with 3.61, $2.55\left(\mathrm{t} \mathrm{ha}^{-1}\right)$, in RFS, the crosses P1 x P9 (1.43) and P2 x P6 (0.83 $\left.\mathrm{t} \mathrm{ha}^{-1}\right)$ stood out (Table 5). The cross P1 x P9 (6.94\%) presented the highest value, for the NFP variable (Table 6). Do Nascimiento et al. (2014) observed that in four of their parents they obtained the highest values for GCA, and their crosses had a higher ACE value, thus indicating that they can be selected with the objective of increasing the yield per plant and obtaining fruits with a greater amount of pulp, high content of dry and fresh biomass. For their part, Rohini and Lakshmanan, (2017), they selected six out of 30 crosses as the best hybrids, since they showed a high Heterobeltiosis, these crosses could be used for subsequent breeding programs.

The variables RFS and NFP showed the highest heterosis effects (54.46 and $36.65 \%$ respectively) and heterobeltiosis (42.34 and 33.2), at the cross P1 x P9 (Table 5 and 6).

Table 4: General combining ability (GCA) of nine populations of Guajillo chili

\begin{tabular}{lccccccccc}
\hline Pob. & RFS & RFF & PFF & PFS & NFP & LF & AF & AP & LP \\
\hline P1 & $-0.31^{* *}$ & $-0.80^{*}$ & $1.94^{* *}$ & $0.30^{* *}$ & $-1.53^{* *}$ & $0.29^{*}$ & -0.04 & -0.54 & $0.20^{* * *}$ \\
P2 & $-0.24^{*}$ & 0.22 & 0.73 & 0.12 & -0.04 & $0.26^{*}$ & $0.17^{*}$ & -0.35 & -0.05 \\
P3 & 0.12 & -0.67 & $-1.34^{* *}$ & -0.15 & 0.49 & $-0.39^{* *}$ & 0.12 & 0.03 & $-0.14^{*}$ \\
P4 & $0.23^{*}$ & $1.19^{* *}$ & 0.86 & 0.15 & 0.78 & $0.40^{* *}$ & 0.11 & 0.8 & $0.14^{*}$ \\
P5 & $0.33^{* *}$ & 0.68 & -0.22 & -0.01 & $1.08^{*}$ & -0.17 & $-0.19^{*}$ & -0.49 & -0.06 \\
P6 & 0.21 & 0.07 & $-2.70^{* * *}$ & $-0.33^{* * *}$ & $0.97^{*}$ & $-0.52^{* * *}$ & -0.11 & 2.29 & $-0.18^{* *}$ \\
P7 & 0.08 & 0.36 & 0.57 & 0.09 & -0.04 & 0.17 & -0.06 & 0.06 & $0.15^{\star *}$ \\
P8 & $-0.53^{* *}$ & $-1.38^{* * *}$ & 0.4 & -0.13 & $-1.94^{* * *}$ & 0.2 & 0.04 & $-2.59^{*}$ & 0.05 \\
P9 & 0.12 & 0.33 & -0.24 & -0.03 & 0.55 & -0.24 & -0.04 & 0.77 & $-0.12^{*}$ \\
\hline
\end{tabular}

${ }^{*},{ }^{* \star},{ }^{* \star *}$ a Different from zero to a probability of $0.05,0.01$ and 0.001 , respectively. Pop: Population; RFS: Yield of dried fruit (t ha-1 $)$;

RFF: Yield of fresh fruit (t ha-1); PFF: Average weight of fresh fruit $(\mathrm{g})$; PFS: Average weight of dried fruit (g); NFP: Number of fruits per plant; LF: Fruit length (cm); AF: Fruit width; AP: Plant height $(\mathrm{cm})$; LP: length of pedicel $(\mathrm{cm})$ 
Hernández-Mendoza, et al.

Table 5: Specific combining ability (SCA), percentage of heterosis (Hm) and heterobeltiosis (Hs) in the Guajillo chili crosses

\begin{tabular}{|c|c|c|c|c|c|c|c|c|c|c|c|c|}
\hline \multirow[t]{2}{*}{ CROSS } & \multicolumn{3}{|c|}{ RFS } & \multicolumn{3}{|c|}{ RFF } & \multicolumn{3}{|c|}{ PFF } & \multicolumn{3}{|c|}{ PFS } \\
\hline & SCA & $\mathrm{Hm} \%$ & Hs \% & SCA & $\mathrm{Hm} \%$ & $\mathrm{Hs} \%$ & SCA & $\mathrm{Hm} \%$ & $\mathrm{Hs} \%$ & SCA & $\mathrm{Hm} \%$ & $\mathrm{Hs} \%$ \\
\hline $\mathrm{P} 1 \times \mathrm{P} 9$ & $1.43^{* * *}$ & $54.46^{\star \star \star}$ & $42.34^{\star *}$ & $3.61^{*}$ & $27.34^{*}$ & 18.65 & -2.68 & 0 & -3.35 & -0.39 & 5.88 & 2.49 \\
\hline $\mathrm{P} 2 \times \mathrm{P} 5$ & 0.34 & 1.62 & -16.87 & 1.18 & 9.68 & 6.95 & 3.02 & $16.96^{* *}$ & $14.10^{*}$ & 0.30 & $14.34^{*}$ & 9.94 \\
\hline $\mathrm{P} 2 \times \mathrm{P} 6$ & $0.83^{*}$ & $35.70^{*}$ & $27.76^{\star}$ & 2.34 & $25.27^{*}$ & 16.78 & 1.34 & 7.08 & 1.83 & 0.39 & 10.61 & 5.63 \\
\hline $\mathrm{P} 3 \times \mathrm{P} 4$ & 0.54 & 13.54 & 1.3 & $2.55^{*}$ & $26.43^{*}$ & 8.47 & 1.51 & $14.08^{*}$ & 10.82 & 0.56 & $25.60^{*}$ & $23.66^{\star *}$ \\
\hline P3×P5 & 0.32 & 5.72 & -8.67 & -0.03 & 4.5 & -8.34 & 0.92 & 9.53 & 7.06 & 0.16 & 13.4 & 10.98 \\
\hline P3×P7 & 0.35 & 11.39 & 5.31 & 0.31 & 6.05 & -6 & -0.08 & 2.81 & -4.61 & 0.04 & 10.14 & 5.44 \\
\hline P3×P9 & 0.12 & $35.08^{*}$ & 19.21 & -1.97 & 6.92 & 5.9 & -3.06 & -1.57 & -7.16 & -0.37 & 7.32 & 1.71 \\
\hline $\mathrm{P} 4 \times \mathrm{P} 6$ & 0.43 & 13.74 & 1.04 & -1.32 & -2.61 & -13.33 & 1.62 & 10.51 & 7.00 & 0.35 & $15.76^{*}$ & $15.64^{*}$ \\
\hline $\mathrm{P} 4 \times \mathrm{P} 9$ & 0.78 & 22.08 & -2.34 & 1.51 & $29.27^{*}$ & 11.81 & -2.36 & $11.73^{*}$ & 8.39 & -0.46 & $18.97^{*}$ & $14.45^{\star}$ \\
\hline $\mathrm{P} 5 \times \mathrm{P} 6$ & 0.12 & 3.08 & -11.33 & 2.03 & $23.05^{\star}$ & 12.07 & $-3.76^{*}$ & -9.3 & -11.64 & -0.52 & -6.04 & -6.71 \\
\hline P7×P9 & 0.43 & 20.7 & 1.47 & 0.76 & 16.39 & 4.05 & 2.66 & 8.82 & 6.94 & 0.04 & $16.43^{*}$ & $15.21^{*}$ \\
\hline
\end{tabular}

${ }^{*},{ }^{* *},{ }^{* \star *}$ a Different from zero at a probability of $0.05,0.01$ and 0.001 , resp. RFS: Yield of dried fruit (t ha $\left.{ }^{-1}\right)$; RFF: Fresh fruit yield (t ha $\left.{ }^{-1}\right)$; PFF: Average weight of fresh fruit (g); PFS: Average weight of dried fruit $(\mathrm{g})$

Table 6: Specific combining ability (SCA), percentage of heterosis ( $\mathrm{Hm})$ and heterobeltiosis (Hs) in the Guajillo chili crosses

\begin{tabular}{|c|c|c|c|c|c|c|}
\hline \multirow[t]{2}{*}{ CROSS } & \multicolumn{3}{|c|}{ NFP } & \multicolumn{3}{|c|}{ LF } \\
\hline & SCA & $\mathrm{Hm} \%$ & $\mathrm{Hs} \%$ & SCA & $\mathrm{Hm} \%$ & Hs \% \\
\hline $\mathrm{P} 1 \times \mathrm{P} 9$ & $6.94^{* * *}$ & $36.65^{*}$ & $33.2^{*}$ & -0.64 & 4.67 & 2.67 \\
\hline $\mathrm{P} 2 \times \mathrm{P} 5$ & 1.27 & 7.57 & -0.32 & 0.74 & $15.03^{* * *}$ & $7.66^{*}$ \\
\hline $\mathrm{P} 2 \times \mathrm{P} 6$ & 2.73 & 24.91 & 23.02 & 0.1 & 7.08 & -0.06 \\
\hline $\mathrm{P} 3 \times \mathrm{P} 4$ & 2.02 & 9.82 & 3.47 & 0.24 & 5.67 & -1.97 \\
\hline P3×P5 & 0 & 0.92 & -2.98 & $0.98^{*}$ & $17.93^{* * *}$ & $16.12^{\star \star \star}$ \\
\hline $\mathrm{P} 3 \times \mathrm{P} 7$ & -0.05 & 0.79 & -2.96 & -0.03 & 3.22 & -2.99 \\
\hline P3×P9 & -0.32 & 8.48 & 0.34 & -0.54 & 4.54 & 1.26 \\
\hline $\mathrm{P} 4 \times \mathrm{P} 6$ & -0.26 & 0.36 & -7.49 & $1.03^{*}$ & $12.78^{\star * *}$ & 2.86 \\
\hline $\mathrm{P} 4 \times \mathrm{P9}$ & 2.94 & 16.96 & 2.43 & -0.01 & 3.93 & -0.62 \\
\hline $\mathrm{P} 5 \times \mathrm{P} 6$ & 2.84 & $25.63^{*}$ & 18.1 & 0.32 & $13.07^{* * *}$ & $12.73^{* *}$ \\
\hline P7×P9 & 1.31 & 21.71 & 16.73 & 0.05 & 3.48 & 0.3 \\
\hline
\end{tabular}

${ }^{*},{ }^{* *},{ }^{* * *}$ aDifferent from zero at a probability of $0.05,0.01$ and 0.001 , resp. NFP: Number of fruits per plant; LF: Length of fruits $(\mathrm{cm})$

Table 7: Specific combining ability (SCA), percentage of heterosis $(\mathrm{Hm})$ and heterobeltiosis $(\mathrm{Hs})$ in the Guajillo chili crosses

\begin{tabular}{lccccccc}
\hline CROSS & \multicolumn{4}{c}{ AP } & & & \multicolumn{3}{c}{ LP } \\
\cline { 2 - 4 } \cline { 7 - 8 } & SCA & Hm \% & Hs \% & & SCA & Hm \% & Hs \% \\
\hline P1×P9 & $10.96^{*}$ & 8.07 & 7.60 & & -0.34 & -2.04 & -4.62 \\
P2×P5 & 6.4 & 9.36 & 4.59 & & 0.30 & 5.88 & 4.83 \\
P2×P6 & -2.01 & -2.56 & -3.7 & & -0.09 & 0.57 & -4.37 \\
P3×P4 & 3.48 & 6.59 & 5.08 & & 0.25 & 5.64 & -1.44 \\
P3×P5 & 2.71 & 8.23 & 5.85 & & $-0.38^{*}$ & -4.66 & -7.04 \\
P3×P7 & $8.40^{*}$ & 7.92 & 3.42 & & 0.12 & 3.36 & -3.7 \\
P3×P9 & -8.5 & -4.41 & -6.87 & & 0.05 & 5.08 & 1.63 \\
P4×P6 & 2.72 & 4.51 & 2.4 & & $0.43^{*}$ & $9.84^{*}$ & 0.98 \\
P4×P9 & 4.76 & 8.09 & 6.81 & & 0.26 & 1.78 & -1.93 \\
P5×P6 & 1.51 & 5.53 & -0.2 & & 0.14 & 6.13 & 1.88 \\
P7×P9 & -6.62 & $-14.89^{* *}$ & $-16.32^{* * *}$ & -0.08 & -4.01 & $-7.65^{*}$ \\
\hline
\end{tabular}

${ }^{*},{ }^{* *},{ }^{* * *}$ a Different from zero at a probability of $0.05,0.01$ and 0.001 , resp. AP: Plant height $(\mathrm{cm})$; LP: Pedicel length $(\mathrm{cm})$

Therefore, these traits could be improved more efficiently by genetic improvement methods that exploit the effects of non-additive gene action, such as hybridization (May et al., 2010). Similar results were reported by Nagaraju and
Sreelathakumary, (2017), in the Capsicum genus where the highest effect of ACE for NFP was registered in the CA6xCA-23 cross, showing significant ACE effects for other characters such as plant height, fruit weight, green fruit yield per plant, fruit length, fruit diameter. For their part, Hernández-Pérez et al. (2011) also found similar results, where the best crosses were $\mathrm{P} 6 \times \mathrm{P} 16$ and $\mathrm{P} 4 \times \mathrm{P} 6$, the P1 x P118 cross showed high yields. For their part, Sitaresmi et al. (2020) report high heterosis for the IPB C8xIPB C19 cross for the weight of fruit per plant and the IPB C8xIPB C15 cross for the highest number of fruits per plant, in IPB C19 the best GCA was found for the weight of fruit per plant. Studies carried out by Medereiros et al. (2014) recorded higher values for SCA and in heterosis in the number of fruits per plant in the hybrids UENF 1616Xuenf1629 and UENF1616Xuenf1732.

The heterosis and heterobeltiosis with the highest value, for PFF is presented at the P2 x P5 cross and for the PFS variable at $\mathrm{P} 3 \times \mathrm{P} 4$ (Table 5).

The effects of the ACE for the highest plant height were presented in the crosses $\mathrm{P} 1 \times \mathrm{P} 9$ and $\mathrm{P} 3 \times \mathrm{P} 7$, with values of 10.96 and $8.40 \mathrm{~cm}$, respectively, the cross P2 x P5 (9.36) presented the highest value of $\mathrm{Hm}$, also, with the cross P1 x P9 the highest value for heterobeltiosis was presented (7.60) (Table 7).

Regarding the effects of SCA for LF, the crosses that showed significant positive values were $\mathrm{P} 3$ × P5 (0.98) and P4 x P6 (1.03) (Table 6). For the LP, the crosses with the greatest significant and positive SCA effect correspond to the P4 x P6 cross (Table 7). Similar results were reported by Medereiros et al. (2014) in crosses of Capsicum baccatum var. pendulum, where they obtained the highest ACE values for the LF variable with the crosses UENF $1616 \mathrm{x}$ UENF 1629 and UENF 1629 x UENF 1639, these authors also reported positive heterosis for most crosses for LF. 
In the expression of heterosis the crosses that presented the highest and most positive values for the LF variable were P2 x P5, P3 x P5, P4 x P6 and P5 x P6 and in P5, while the crosses with the highest $\mathrm{Hs}$ for the same variable were P2 x P5, P3 x P5 and P5 x P6 with values of 7.66, 16.12 and $12.73 \%$ respectively (Table 6 ). These results are similar with those of Rao and Reddy, (2016), for the variables AP, LF, PF and fruit yield. Other similar results were observed by Nagaraju and Sreelathakumary, (2017), for the variables AP, LF, PF, NFP and. For the LP variable, the highest value of heterosis was in the cross P4 x P6 (9.84) and for heterobeltiosis, it was observed in the cross P2 x P5 (4.83). Similar results were reported by Patel et al. (2010), with a heterobeltiosis of $24.24 \%$ when crossing AVNPC-131 $\mathrm{x}$ acs-03-14. The estimate of heterosis showed that the number of crosses with heterosis was higher compared to heterobeltiosis for all variables. These results are similar with those of Bhutia et al. (2015), for AP, LF, RFP and NFP; Singh et al. (2012), for AP; and NFP; Patel et al. (2010), for LF.

In Mexico, several species of plants were domesticated, including that of chili, which has been one of the main crops of economic and cultural importance. Due to its importance, there is a need to generate new materials to supply the national and international market.

Heterosis can be extrapolated as the sum total of many physiological and phenotypic traits including vegetative growth rate Baranwal et al. (2012). Most parental inbred lines have a small number of upper alleles, high-yielding hybrid varieties have several; therefore, the accumulation of numerous rare superior alleles with positive dominance is an important contributor to heterotic phenomena (Huang et al., 2015). Heterosis as a genetic tool has an important role in crop yields and in many cases of commercial importance, such as tomato, watermelon, cabbage, cauliflower and cucumber (Vaishnav et al., 2009).

The populations used for the Guajillo pepper show significant differences for the yield variables, indicating their high divergence and ability to combine with each other, obtaining in this way a high SCA which can present a positive but significant impact on the fresh and dry fruit yield. Thus, it is possible to take advantage of such heterotic effects that will be fixed in subsequent generations, in addition, select the parents with good agronomic behavior of their hybrids (Méndez-Natera et al. (1997) in our study, the crosses P5 X P6 and P1 x P9 presented a greater number of fruits, giving high values for both heterosis in the first cross and heterosis and herobeltiosis in the second. Desired characteristics in the improvement of Capsicum is the length of the fruit and our results highlight a good behavior of the crosses for this character, which included the crosses:
P3 x P5, P4 x P6, P5 x P6. The commercialization of this species of chili is dry, therefore, some of the crosses with high heterosis and heterobeltiosis values that stood out were; P1 x P9, P2 x P6 and P3 x P4.

The positive combination capacity of the populations to generate hybrids with favorable performance characteristics, indicates the predominance of the action of the additive gene in the inheritance for said variable. The action of an additive gene in inheritance has been observed in capsaicinoids in C. pubescens (Zewdie et al., 2001). Studies have suggested that hybridization is the most suitable breeding method for obtaining high yields and a greater number of fruits per plant in C. annum, based on GCA and heterosis studies (May et al., 2010). Hybrids with good yield potential and fruit characteristics in Capsicum can be developed from the parents (Geleta and Labuschagne, 2004). Crossbreeding involving related distant relatives provides a broad spectrum of variability that ensures greater selection efficiency for better genotypes (Banerjee et al., 2007). Isolation of pure lines from heterotic F1 progenies is one possible way to improve fruit yield and chili quality (Khalil and Hatem, 2014). Studies carried out by Do Rêgo et al. (2011) also found positive values in the GCA and SCA related to the quality of the fruit of chili peppers (fruit weight, fruit width, fruit length and pericarp thickness). However, plant breeders require a more detailed scientific understanding of heredity or heritability potential for the expression of these traits of interest, to more effectively exploit parent lines and produce superior hybrids (Butcher et al., 2013). It has been observed in many cases that the best parent of the developed hybrid is inferior to the commercial varieties; therefore, a good selection of parents with better heterotic response should be carried out (Shrestha et al., 2011). The systemic approach to developing F1 hybrids in any crop depends mainly on the magnitude of the desirable heterosis (Sharma et al., 2013). New studies for the genetic improvement of the Capsicum genus suggest weighted correlation networks, to discover correlation structures and link patterns in morpho-agronomic characteristics Silva et al., (2016), which would help to increase the effectiveness in the selection of the genotype. In chili peppers for being a rich source of nutrients of utmost importance in the human diet and for preventing diseases such as cancer and cardiovascular diseases, it is necessary to increase the yield potential (Sood and Kumar, 2010).

Finally, hybrid development programs must be continuous so that the seeds are available to producers at an affordable cost (Chaudhary et al., 2013). Also, efforts should focus on the development of male sterility-based hybrids using cytoplasmic male sterile lines to minimize the cost of F1 seeds (Tembhurne and Rao, 2012). Also, the molecular 
markers developed for mapping and assisted selection in the improvement of chili peppers should be used (Minamiyama et al., 2006; Ince et al., 2010), but also, C. annum populations in Mexico are a valuable resource that must be conserved (Pacheco-Olvera et al., 2012). Future investigations of the Guajillo pepper of interest should include aspects such as the physiology of the seed, vigor, germination, volumetric weight of roots and resistance to biotic and abiotic stress.

\section{CONCLUSIONS}

The populations that presented the highest GCA for dry yield were $\mathrm{P} 5$ and $\mathrm{P} 4$ with 0.33 and 0.23 respectively, which makes them of great potential to be used as populations in Chili breeding programs. Populations were identified whose crosses originated plants with desirable characteristics mainly for RFS, RFF and NFP for both GCA, heterosis and heterobeltiosis (P1 x P9 and P2 x P6).

\section{ACKNOWLEDGEMENT}

We want to thank the College of Postgraduates (COLPOS) and the Mexican Council of Science and Technology (CONACYT) for the doctoral scholarship awarded.

\section{Author's contributions}

Fanny Hernández-Mendoza conducted the greenhouse and field experiments, collected the data, performed the statistical analyses, and wrote her $\mathrm{PhD}$ dissertation based on this project. Tarsicio Corona-Torres directed the project, and review of the manuscript. Víctor García-Gaytán support in greenhouse experiment, editing and formatting of the manuscript. Irma Sanchez-Cabrera support in greenhouse experiment and laboratory. Víctor Heber Aguilar-Rincón collaborated in the project. Fernando Carlos Gómez-Merino collaborated in the project and review of the manuscript.

\section{REFERENCES}

Banerjee, R., S. Roychowdhuri, H. Sau, B. K. Das, P. Ghosh and B. Saratchandra. 2007. Genetic diversity and interrelationship among mulberry genotypes. J. Genet. Genomics. 34: 691-697.

Baranwal, V. K., V. Mikkilineni, U. B. Zehr, A. K. Tyagi and S. Kapoor. 2012. Heterosis: Emerging ideas about hybrid vigour. J. Exp. Bot. 63: 6309-6314.

Bhutia, N. D., T. Seth, V. D. Shende, S. Dutta and A. Chattopadhyay. 2015. Estimation of Heterosis, dominance effect and genetic control of fresh fruit yield, quality and leaf curl disease severity traits of chilli pepper (Capsicum annuum L.). Sci. Hortic. 182: 47-55.

Bravo, L., G. Galindo and M. Amador. 2006. Tecnología de producción de chile seco. Vol. 5. INIFAP CIRNOC Campo Express
Zacatecas Libro Téc, p. 222.

Butcher, J. D., K. M. Crosby, K. S. Yoo, B. Patil, J. L. Jifon and W. L. Rooney. 2013. Heterosis in different F1 Capsicum annuum genotypes for fruit traits, ascorbic acid, capsaicin, and flavonoids. Sci. Hortic. 159: 72-79.

Chaudhary, A., R. Kumar and S. Solankey. 2013. Estimation of heterosis for yield and quality components in chilli (Capsicum annuum L.). Afr. J. Biotechnol. 12: 6605-6610.

Costa, M. P. S., M. M. Rêgo, A. P. G. Silva, E. R. Rêgo and P. A. Barroso. 2016. Characterization and genetic diversity of pepper (Capsicum spp) parents and interspecific hybrids. Genet. Mol. Res. 15: 1-12.

Do Rêgo, E. R., M. M. Do Rêgo, C. D. Cruz, F. L. Finger and V. W. D. Casali. 2011. Phenotypic diversity, correlation and importance of variables for fruit quality and yield traits in Brazilian peppers (Capsicum baccatum). Genet. Resour. Crop. Evol. 58: 909-918.

Esquivel-Esquivel, G., F. Castillo-González, J. M. Hernández-Casillas, A. Santacruz-Varela, G. García de los Santos, J. A. AcostaGallegos, and A. Ramírez Hernández. 2011. Heterosis en maíz del Altiplano de México con diferente grado de divergencia genética. Rev. Mex. Cienc. Agríc. 2: 331-344.

García-Gaytán, V., F. C. Gómez-Merino, L. I. Trejo-Téllez, G. A. Baca-Castillo and S. García-Morales. 2017. The Chilhuacle Chili (Capsicum annuum L.) in Mexico: Description of the variety, its cultivation, and uses. Int. J. Agron. 2017: 5641680.

Geleta, L. and M. Labuschagne. 2004. Hybrid performance for yield and other characteristics in peppers (Capsicum annuum L.). J. Agric. Sci. 142: 411-419.

Geleta, L. F. and M. T. Labuschagne. 2006. Combining ability and heritability for Vitamin $C$ and total soluble solids in pepper (Capsicum annuum L.). J. Sci. Food. Agric. 86: 1317-1320.

Greenleaf, W. 1986. Pepper breeding. In: Breeding Vegetable Crops. AVI, Westport, Connecticut, USA, pp. 67-134.

Griffing, B. 1956. Concept of general and specific combining ability in relation to diallel crossing systems. Aust. J. Biol. Sci. 9: 463-493.

Gutiérrez, E., A. Espinoza, A. P. Gil, and J. J. Lozano and O. Antuna. 2004. Aptitud combinatoria de híbridos de maíz para la Comarca Lagunera. Rev. Fitotec. Mex. 27: 7-11e

Hasanuzzaman, M., M. A. Hakim, J. Fersdous, M. M. Islam and L. Rahman. 2012. Combining ability and heritability analysis for yield and yield contributing characters in chilli (Capsicum annuum) landraces. Plant Omics. 5: 337-344.

Hernández-Pérez, M., A. López-Benítez, F. Borrego-Escalante, S. R. López-Betancourt and M. Ramírez-Meraz. 2011. Análisis dialélico del rendimiento de Chile por el Método IV de griffing. Agron. Mesoam. 22: 37-43.

Huang, X., S. Yang, J. Gong, Y. Zhao, Q. Feng, H. Gong and N. Chen. 2015. Genomic analysis of hybrid rice varieties reveals numerous superior alleles that contribute to heterosis. Nat. Commun. 6: 1-9.

Ince, A. G., M. Karaca, and A. N. Onus. 2010. Polymorphic microsatellite markers transferable across Capsicum species. Plant. Mol. Biol. Report. 28: 285-291.

IPGRI. 1995. CATIE. Descriptors for Capsicum (Capsicum spp.). International Plant Genetic Resources Institute, Rome, Italy; the Asian Vegetable Research and Development Center, Taipei, Taiwan, and the Centro Agronómico Tropical de Investigación y Enseñanza, Turrialba Costa Rica, p. 110.

Khalil, M. R. and M. Hatem. 2014. Study on combining ability and heterosis of yield and its components in pepper (Capsicum annum L.). Alexantia. J. Agric. Res. 59: 61-71. 
De la Cruz-Lázaro, D., G. Castañón-Nájera, N. P. Brito-Manzano, A. Gómez-Vázquez, V. Robledo-Torres and A. J. Lozano del Río. 2010. Heterosis y aptitud combinatoria de poblaciones de maíz tropical. Phyton B Aires. 79: 11-17.

Martínez-Vázquez, E., A. Hernández-Bautista, R. Lobato-Ortiz, J. J García-Zavala and D. Reyes-López. 2017. Exploring the breeding potential of Mexican tomato landraces. Sci. Hortic. 220: 317-325.

Medeiros, A. M., R. Rodrigues, L. S. A. Gonçalves, C. P. Sudré, H. S. D. Oliveira and M. H. D. Santos. 2014. Gene effect and heterosis in Capsicum baccatum var. pendulum. Ciênc. Rural. 44: 1031-1036.

Méndez-Natera, J., A. Rondón and J. Merazo-Pinto. 1997. Heterobeltiosis en algodón (Gossypium hirsutum L.): Rendimiento de algodón en rama, sus componentes y calidad de la fibra. Bioagro. 9: 77-85.

Minamiyama, Y., M. Tsuro and M. Hirai. 2006. An SSR-based linkage map of Capsicum annuum. Mol. Breed. 18: 157-169.

Nagaraju, M. M. and I. Sreelathakumary. 2017. Combining ability analysis for growth and yield characters in chilli (Capsicum annuum L). Int. J. Farm. Sci. 6: 207-212.

Nascimiento, M. F., C. H. Bruckner, F. L. Finger, N. F. D. Nascimento, E. R. D. Rêgo and M. M. D. Rego. 2014. Combining ability for yield and fruit quality in the pepper Capsicum annuum. Genet. Mol. Res. 13: 3237-3249.

Pacheco-Olvera, A., S. Hernández-Verdugo, V. Rocha-Ramírez, A. González-Rodríguez and K. Oyama. 2012. Genetic diversity and structure of pepper (Capsicum annuum L.) from Northwestern Mexico analyzed by microsatellite markers. Crop. Sci. 52: 231-241.

Patel, M., A. Patel, J. Patel and J. Patel. 2010. Heterosis for green fruit yield and its components in chilli (Capsicum annuum var. longicum (DG) Sendt) over environments. Electron. J. Plant. Breed. 1: 1443-1453.

Pech, A. M., G. C. Nájera, J. M. Tun-Suárez, M. Mendoza-Elos, J. O. Mijangos-Cortés, A. P. Gutiérrez and L. LatournerieMoreno. 2010. Efectos heteróticos y aptitud combinatoria en poblaciones de chile dulce (Capsicum annuum L.). Rev. Fitotec. Mex. 33: 353-360.

Perry, L. and K. V. Flannery. 2007. Precolumbian use of chili peppers in the Valley of Oaxaca, Mexico. Proc. Natl. Acad. Sci. U. S. A. 104: 11905-11909.

Rao, P. G. and K. M. Reddy. 2017. Exploitation of mid parent heterosis in bell pepper (Capsicum annuum L.) for yield and yield attributing traits. Agric. Res. J. 54: 117-119.

Rohini, N. and V. Lakshmana. 2017. Heterotic expression for dry pod yield and its components in chilli (Capsicum annuum var. annuum). J. Anim. Plant. Sci. 27: 207-218.

Sharma, V. K., S. Punetha and B. B. Sharma. 2013. Heterosis studies for earliness, fruit yield and yield attributing traits in bell pepper. Afr. J. Agric. Res. 8: 4088-4098.

Shrestha, S. L., B. P. Luitel and W. H. Kang. 2011. Heterosis and heterobeltiosis studies in sweet pepper (Capsicum annuum L.). Hortic. Environ. Biotechnol. 52: 278-283.

Silva, A. R. D., E. R. Do Rêgo, A. M. Do Santos Pessoa and M. M. Do. Rêgo. 2016. Correlation network analysis between phenotypic and genotypic traits of chili pepper. Pesqui. Agropecuária Bras. 51: 372-377.

Singh, D., T. Pramod and S. Jain. 2012. Heterosis studies for growth, flowering, and yield of chilli (Capsicum annuum L.). Pantnagar. J. Res. 10: 61-65.

Sitaresmi, T., S. Sujiprihati and M. Syukur. 2016. Combining ability of several introduced and local chilli pepper (Capsicum annuum L.) genotypes and heterosis of the offsprings. J. Agron. Indones. Indones. J. Agron. 38: 212-217.

Sood, S. and N. Kumar. 2010. Heterosis for fruit yield and related horticultural traits in bell pepper. Int. J. Veg. Sci. 16: 361-373.

Sprague, G. F. and L. A. Tatum. 1942. General vs. specific combining ability in single crosses of corn. Agron. J. 34: 923-932.

Steiner, A. A. 1966. The influence of the chemical composition of a nutrient solution on the production of tomato plants. Plant Soil. 24: 454-466.

Sudré, C. P., R. Rodrigues, E. M. Riva, M. Karasawa and A. T. D. A. Júnior. 2005. Divergência genética entre acessos de pimenta e pimentão utilizando técnicas multivariadas. Hortic. Bras. 23: 22-27.

Tembhurne, B. and S. Rao. 2012. Heterosis and combining ability in CMS based hybrid chilli (Capsicum annuum L.). J. Agric. Sci. 4: 89-96.

Vaishnav, R., K. Srivastava and P. Singh. 2009. Heterosis and combining ability in chilli for yield and yield contributing traits (Capsicum annuum L.). Asian. J. Bio. Sci. 4: 244-248.

Wang, D. and P. W. Bosland. 2006. The genes of Capsicum. HortScience. 41: 1169-1187.

Wynne, J., D. Emery and P. Rice. 1970. Combining ability estimates in Arachis hypogaea L. II. field performance of F1 hybrids. Crop. Sci. 10: 713-715.

Zewdie, Y., P. W. Bosland and R. Steiner. 2001. Combining ability and heterosis for capsaicinoids in Capsicum pubescens. HortScience 36: 1315-1317.

Zhang, Y. and M. S. Kang. 2003. DIALLEL-SAS: A Program for Griffing's Diallel Methods. Haworth Press Inc., New York, USA. 